\title{
Breast Cancer cN3a TNM Finding v8
}

National Cancer Institute

\section{Source}

National Cancer Institute. Breast Cancer cN3a TNM Finding v8. NCI Thesaurus. Code C139405.

Breast cancer with metastases in ipsilateral infraclavicular lymph node(s). (from AJCC 8th Ed.) 